Journal of the Electrochemical Society, Vol. 149, No. 5, 2002, pp. B179-B185B.

ISSN: 0013-4651

DOI: $10.1149 / 1.1469031$

http://www.electrochem.org/

http://scitation.aip.org/getpdf/servlet/GetPDFServlet?filetype=pdf\&id=JESOAN00014900000500B179000001\&idty

pe $=$ cvips $\&$ prog $=$ normal

(C) The Electrochemical Society, Inc. 2002. All rights reserved. Except as provided under U.S. copyright law, this work may not be reproduced, resold, distributed, or modified without the express permission of The Electrochemical Society (ECS). The archival version of this work was published in Journal of the Electrochemical Society, Vol. 149, No. 5, 2002, pp. B179-B185B.

\title{
A Galvanic Corrosion Approach to Investigating Chromate Effects on Aluminum Alloy 2024-T3
}

\section{William J. Clark, ${ }^{a}$ Jeremy D. Ramsey, ${ }^{\mathrm{a}, *}$ Richard L. McCreery, ${ }^{\text {a, } * *, \mathrm{z}}$ and Gerald S. Frankel $^{\mathbf{b}, * *}$}

${ }^{a}$ Department of Chemistry and ${ }^{b}$ Department of Materials Science and Engineering, The Ohio State University, Columbus, Ohio

*Electrochemical Society Student Member. **Electrochemical Society Active Member

The effects of chromate treatment on the corrosion of an aluminum/copper aircraft alloy were examined with a galvanic corrosion apparatus composed of two electrodes and a zero resistance ammeter. Combinations of pure $\mathrm{Al}$, pure $\mathrm{Cu}$, and $\mathrm{AA2024}-\mathrm{T} 3$ electrodes were immersed in $0.1 \mathrm{M} \mathrm{NaCl}$ solution, which was saturated with air, $\mathrm{O}_{2}$, or argon. Selection of electrode material or differential aeration resulted in partial segregation of corrosion reactions, with one electrode becoming a net cathode and the other a net anode. For the case of an $\mathrm{Al} / \mathrm{Cu}$ galvanic cell, chromate significantly reduced the observed cathodic current on $\mathrm{Cu}$ but had little effect when added to the Al cell. For an AA2024/AA2024 couple, chromate decreased the observed current when present in either the net anode or net cathode compartments. The results indicate that $\mathrm{Cr}^{\mathrm{VI}}$ in solution, or $\mathrm{Cr}^{\mathrm{VI}}$ pretreatment, inhibits $\mathrm{O}_{2}$ reduction on $\mathrm{Cu}$ sites. Inhibition is preceded by a spike in the reduction current, implying that $\mathrm{Cr}^{\mathrm{III}}$ is formed at approximately a monolayer level on $\mathrm{Cu}$. The results for $\mathrm{Cr}^{\mathrm{VI}}$ effects on the AA2024/AA2024 galvanic couple are consistent with observed polarization curves. Considering the results in their entirety, $\mathrm{Cr}^{\mathrm{VI}}$ acts as a strong irreversible cathodic inhibitor on $\mathrm{Cu}$ and $\mathrm{AA} 2024$, but the results do not exclude the action of $\mathrm{Cr}^{\mathrm{VI}}$ as an anodic inhibitor on AA2024-T3.

Aluminum alloy 2024-T3 (AA2024-T3) has been well documented to be highly susceptible to corrosion, particularly localized pitting corrosion, and intergranular corrosion. AA2024-T3 is an in-homogeneous alloy (nominal composition $\mathrm{Al}, 3.8-4.9 \% \mathrm{Cu}, 1.2-1.8 \% \mathrm{Mg}$, $0.3-0.9 \% \mathrm{Mn}, 0.5 \% \mathrm{Fe}, 0.5 \% \mathrm{Si}, 0.25 \% \mathrm{Zn}, 0.1 \% \mathrm{Cr}, 0.05 \% \mathrm{Ti}$ ) containing several types of secondary-phase intermetallic particles that are enriched in alloying elements $v s$. the alloy matrix. ${ }^{1}$ Explanations for increased corrosion susceptibility for AA2024-T3 center on the existence of these particles. Intermetallic particles greater than $0.2 \mu \mathrm{m}$ have been characterized into four groups, accounting for about $85 \%$ of particle types, classified as $\mathrm{Al}_{2} \mathrm{CuMg}$ (S-phase), $\mathrm{Al}_{6}(\mathrm{Cu}, \mathrm{Mn}, \mathrm{Fe}), \mathrm{Al}_{7} \mathrm{Cu}_{2} \mathrm{Fe}$, and $(\mathrm{Al}, \mathrm{Cu})_{6} \mathrm{Mn}$ phases. The open-circuit potential $(\mathrm{OCP})$ of many of these intermetallic particles is positive (or becomes positive after dealloying) vs. the alloy matrix phase. $^{3,4}$ Subsequently, local galvanic couples occur with the intermetallic sites becoming cathodes. This may explain the observation of pitting of the alloy matrix around these intermetallic particles. ${ }^{1,5,6}$ Recent advances have revealed that $S$-phase particles dealloy, leaving mostly a copper sponge-like residue. ${ }^{1,2,7,8} \mathrm{Al}_{2} \mathrm{CuMg}$ particles have OCP values negative of the alloy matrix and thus are initially anodic. ${ }^{4,9}$ Another study using scanning Kelvin probe force 
microscopy found the $\mathrm{Al}_{2} \mathrm{CuMg}$ particles to be more noble than the matrix in the as-polished condition due to a surface film. ${ }^{10,11}$ Film damage (either by scratching or prolonged exposure to chloride) caused the potential of the particles to become active relative to the alloy matrix and dissolution ensued. $\mathrm{Mg}$ and $\mathrm{Al}$ dissolution from these particles can result in the above-mentioned porous copper residue that is presumably highly cathodic. Copper from the intermetallic sites has been shown to migrate during the corrosion process and secondary corrosion occurs at sites where it is deposited. ${ }^{4,7}$ Whether this migration results from dissolution or deattachment is not clear.

Chromate conversion coatings (CCCs) have long been used to control corrosion of AA2024-T3 and other metal alloys. However, research has been ongoing to develop alternative corrosion inhibitors due to the toxicity of chromium compounds. A major area of study in this regard is the elucidation of the inhibition mechanism of chromium species, particularly the activity of $\mathrm{Cr}^{\mathrm{VI}}$ as a cathodic or anodic inhibitor, or both. ${ }^{3,12-19}$ The mechanism of CCC formation has been examined, revealing the reduction of solution-phase $\mathrm{Cr}^{\mathrm{VI}}$ to form a $\mathrm{Cr}^{\mathrm{III}}(\mathrm{OH})_{3}$ film and subsequent incorporation of $\mathrm{Cr}^{\mathrm{VI}}$ into the film as a $\mathrm{Cr}^{\mathrm{III}}-\mathrm{Cr}^{\mathrm{VI}}$ mixed oxide. ${ }^{20-23}$ Furthermore, the release of the incorporated $\mathrm{Cr}^{\mathrm{VI}}$ species into solution from the $\mathrm{CCC}$ has been demonstrated, as has migration to pits or defects. ${ }^{14,15}$ The $\mathrm{pH}$ and concentration-dependent release of $\mathrm{Cr}^{\mathrm{VI}}$ aids in explaining the active inhibitor (or self-healing) properties of CCCs. A fundamental question that needs to be answered is whether chromium acts as an inhibitor of anodic and/or cathodic processes taking place during corrosion of the alloy. Anodic inhibition mechanisms of chromate have been studied extensively. Initial ideas of CCC inhibition centered on the formation of a $\mathrm{Cr}^{\text {III }}$ film that sealed the alloy surface from the corrosive electrolyte. ${ }^{21,24}$ In this model, cracks or holes formed in the film are plugged by $\mathrm{Cr}_{2} \mathrm{O}_{3}$ [or $\left.\mathrm{Cr}(\mathrm{OH})_{3}\right]$ as a result of the reduction of $\mathrm{Cr}^{\mathrm{VI}}$ from the CCC. Accumulation of a $\mathrm{Cr}^{\mathrm{VI}}-\mathrm{Al}^{\mathrm{III}}$ mixed oxide has been observed in actively growing pits but reduction to $\mathrm{Cr}^{\mathrm{III}}$ was not reported. Others have presented research on pure aluminum indicating that $\mathrm{CCC}$ formation results in a positively charged surface that effectively repels aggressive chloride anions. ${ }^{26-28}$ However, solution-phase $\mathrm{Cr}^{\mathrm{VI}}$ was not observed to reduce aluminum dissolution according to one study. The possibility of cathodic inhibition by chromium compounds has not been studied thoroughly for aluminum alloys. However, thin films of $\mathrm{Cr}^{\mathrm{III}}$ formed on platinum and gold electrodes from reduction of $\mathrm{Cr}^{\mathrm{VI}}$ effectively inhibited several reduction reactions (including oxygen). ${ }^{29,30}$ Sehgal et al. showed that the attack of AA2024-T3 at open circuit was eliminated by the introduction of a small amount of dichromate into the chloride solution, whereas large amounts of dichromate were needed to have a small effect at an applied potential just above the open-circuit value. ${ }^{19}$ This result implied strong cathodic inhibition by $\mathrm{Cr}^{\mathrm{VI}}$.

Difficulty in studying the corrosion of AA2024-T3 and its inhibition arises due to multiple reactions taking place in the same nominal surface area. Previous studies have utilized current density and potential mapping to study local phenomena on AA2024-T3. ${ }^{10,11,31}$ Additional understanding of the inhibition mechanism might be available by partial or complete segregation of the anodic and cathodic reactions. By employing separate coupled electrodes, galvanic currents may be studied as related to the individual reactions. Furthermore, a galvanic coupling experiment in which a segregated anode and cathode are connected but allowed to float without an externally applied potential approximates the mixed potential relevant to field conditions. Unlike the polarization curves often used to study inhibition, a galvanic coupling experiment does not impose an externally applied potential, which may represent a possibly large current source to drive corrosion. Major differences in chromate effects on AA2024 corrosion 


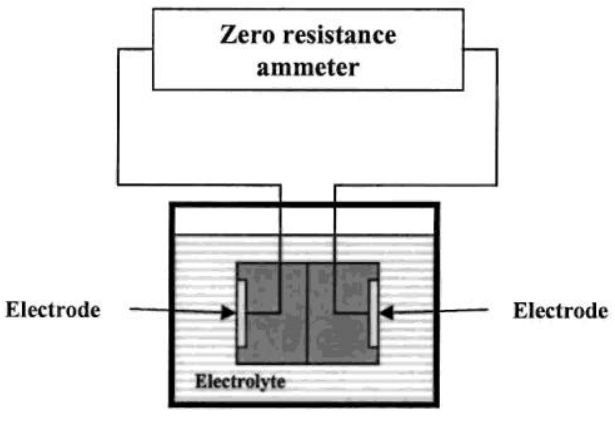

Single cell

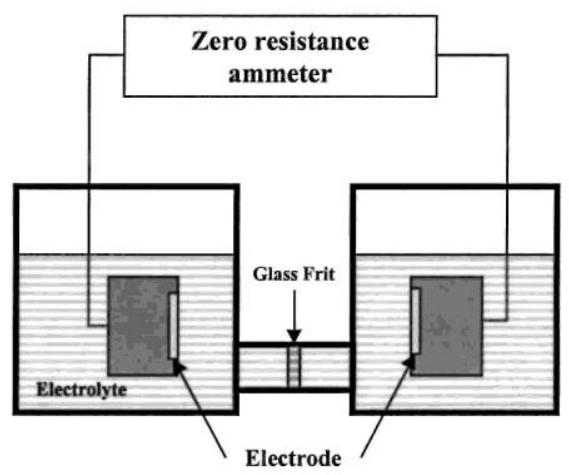

Split cell

Figure 1. Schematics of single- and split-cell apparatus. Solution compartments could be saturated with Ar, $\mathrm{O}_{2}$, or air, and Al, Cu, or AA2024-T3 electrodes were mounted in epoxy resin.

have been reported when foil penetration experiments at open circuit were compared to potentiostatic experiments involving an imposed potential. ${ }^{18,19}$ Previously, Liao and Wei used a segregated anode and cathode to establish relationships between the current density and cathode:anode area ratio for aluminum coupled to model alloys. ${ }^{32}$ The general approach involves two metal samples in separate compartments, with one sample acting as a net cathode and the other a net anode. When one electrode is pure $\mathrm{Cu}$ and the other pure $\mathrm{Al}$, the cathodic and anodic reactions are largely segregated, and the observed current mimics the corrosion current in $\mathrm{Al} / \mathrm{Cu}$ alloys. However, localized corrosion of $\mathrm{Al}$ or $\mathrm{Al}$ alloys in the form of pitting or grain boundary attack always involves some amount of local hydrogen evolution as a result of the low potential at the active site. The amount of hydrogen evolution has been measured to be about $15 \%$ of the anodic current. $^{16,33}$ AA2024-T3/copper cells allow the cathodic reaction to proceed on both electrodes while anodic reactions occur mainly on AA2024. When both electrodes are made from AA2024, the cathodic reaction may be localized preferentially at one electrode by purging one side with oxygen and the other with argon. In the current work, various combinations of electrodes were studied in either a single-cell or split-cell configuration shown in Fig. 1. The split cell employs a porous glass frit that allows ion migration but restricts bulk mixing of the two solutions. The environments of the two chambers in the split cell may be altered independently, thus allowing for more selective control of the anodic and cathodic reactions. The galvanic current between the electrodes is measured with a potentiostat-based zero-resistanceammeter (ZRA) similar to the continuous reading ZRA configuration reported by Jones ${ }^{34,35}$ and Devay et $a l .{ }^{36}$ The approach leads to an admittedly imperfect separation of anodic and cathodic reactions but does permit observations of $\mathrm{Cr}^{\mathrm{VI}}$ effects on both processes.

\section{Experimental}

Barnstead NanoPure ${ }^{\mathrm{TM}}$ water with a resistivity of $18 \mathrm{Mil} \mathrm{cm}$ was used for rinsing and solution preparation in all cases. Reagent-grade $\mathrm{K}_{2} \mathrm{Cr}_{2} \mathrm{O}_{7}$ (Alfa Aesar) and Alodine ${ }^{\mathrm{TM}} 1200 \mathrm{~S}$ powder (Henkel Corp.) were used to make $\mathrm{Cr}^{\mathrm{VI}}$ solutions. Reagent-grade $\mathrm{HNO}_{3}($ Fisher 
Scientific) was used for $\mathrm{pH}$ adjustment. Electrodes were made from commercial Al (99.999\%, $0.5 \mathrm{~mm}$ thick sheet, Alfa Aesar), $\mathrm{Cu}$ (99.99\% $1.0 \mathrm{~mm}$ thick sheet, Alfa Aesar), and $\mathrm{Cu}$ (99.99\%, $5 \mathrm{~mm}$ diam rod, Goodfellow Metals), and aluminum alloy 2024-T3 (0.025 in. thick sheet, ALCOA). Sheet samples were cut to $1 \mathrm{~cm}^{2}$ in all cases, attached to copper wire with silver epoxy resin (SPI Supplies/Structure Probe, Inc.), and embedded in epoxy (Buelher). They were then mechanically polished with successively finer Si:C papers (Buelher: 240, 400, 600, 800, 1200 grit), rinsed with water, and dried under a stream of hot air.

Sample pretreatment with $\mathrm{Cr}^{\mathrm{VI}}$ solutions was performed in some experiments as noted in the text. For Alodine ${ }^{\mathrm{TM}} 1200 \mathrm{~S}$ pretreatment the polished sample was immersed in Alodine ${ }^{\mathrm{TM}}$ $1200 \mathrm{~S}$ solution $\left(7.6314 \mathrm{~g} / \mathrm{L}\right.$ with $\mathrm{HNO}_{3}$ added to $\left.\mathrm{pH} 1.25\right)$ for $5 \mathrm{~min}$, rinsed with water, allowed to air-dry for $2 \mathrm{~h}$, and used immediately. For $\mathrm{Cr}_{2} \mathrm{O}_{7}^{2-}$ pretreatment the polished sample was immersed in $0.4 \mathrm{M} \mathrm{K}_{2} \mathrm{Cr}_{2} \mathrm{O}_{7}$ for $2 \mathrm{~h}$, rinsed with water, allowed to air-dry for $2 \mathrm{~h}$, and used immediately.

Electrochemical measurements were performed using a Gamry Instruments PC3/300 potentiostat/galvanostat/ZRA with Framework ${ }^{\mathrm{TM}}$ (version 3.11) and $\mathrm{DC} 105^{\mathrm{TM}} \mathrm{dc}$ corrosion measurement software. Galvanic current experiments were performed in either single-cell or split-cell configuration as shown in Fig. 1. Galvanic current between the two electrodes and potential of the system was measured using the Gamry hardware in ZRA configuration. Potentiodynamic polarization experiments were performed using a standard three-electrode electrochemical cell. Experiments utilized $\mathrm{Ag} / \mathrm{AgCl}$ as the reference electrode (all potentials quoted are with respect to this reference), $\mathrm{Pt}$ wire as the counter electrode, and $0.1 \mathrm{M} \mathrm{NaCl}$ as the electrolyte. Compressed $\mathrm{O}_{2}$ and $\mathrm{Ar}$ (prepurified) were used for aeration/deaeration studies. Solution additions were made using $0.05 \mathrm{M} \mathrm{K}_{2} \mathrm{Cr}_{2} \mathrm{O}_{7}\left[0.1 \mathrm{M}\right.$ total $\left.\mathrm{Cr}^{\mathrm{VI}}\right]$ in $0.1 \mathrm{M} \mathrm{NaCl}$ as noted in the text and figures. The $\mathrm{pH}$ of $\mathrm{NaCl}$ solutions preceding $\mathrm{Cr}^{\mathrm{VI}}$ addition was uncontrolled, but was typically 5.5-6.0, and decreased by less than 1 unit upon addition of $\mathrm{Cr}^{\mathrm{VI}}$. Injection experiments with controlled $\mathrm{pH}^{37}$ showed only minor differences in galvanic response for $\mathrm{pH} 4$ 6.

\section{Results}

The "single" cell (Fig. 1) with pure $\mathrm{Al}$ and $\mathrm{Cu}$ electrodes was examined initially, since they should provide the greatest segregation of anodic and cathodic reactions. The effects of convection, aeration, and inhibition by $\mathrm{Cr}^{\mathrm{VI}}$ addition on the current for the $\mathrm{Al} / \mathrm{Cu}$ cell are shown in Fig. 2. A stable current of about $-30 \mu \mathrm{A}$ and mixed potential of about $-650 \mathrm{mV}$ was initially established under quiescent conditions. Negative current refers to electron flow from aluminum to copper. Solution stirring and oxygen saturation caused an increase in the current by an order of magnitude while the potential increased to about $-550 \mathrm{mV}$. Deaeration of the solution with argon caused the current to decrease to a level similar to that of the quiescent solution even with solution stirring, while the potential decreased to about $-750 \mathrm{mV}$. Reintroducing oxygen to the system returned the current and potential to previous levels. Addition of $\mathrm{K}_{2} \mathrm{Cr}_{2} \mathrm{O}_{7}$ (to a total of 50 $\mathrm{mM} \mathrm{Cr}{ }^{\mathrm{VI}}$ ) to the system resulted in an immediate reduction in the galvanic current. Even with oxygen saturation and stirring, the current was below that of the quiescent or deaerated solution prior to $\mathrm{Cr}^{\mathrm{VI}}$ addition. Closer examination of the current reveals that the same trends occurred for aeration/deaeration and stirring as observed for the uninhibited system but at greatly reduced current levels. The potential decreased after $\mathrm{Cr}^{\mathrm{VI}}$ was added but gradually returned to $-650 \mathrm{mV}$. After changing from Ar to $\mathrm{O}_{2}$ saturation or back, the potential slowly returned to $\sim-650 \mathrm{mV}$. In 
addition, both the current and potential exhibited

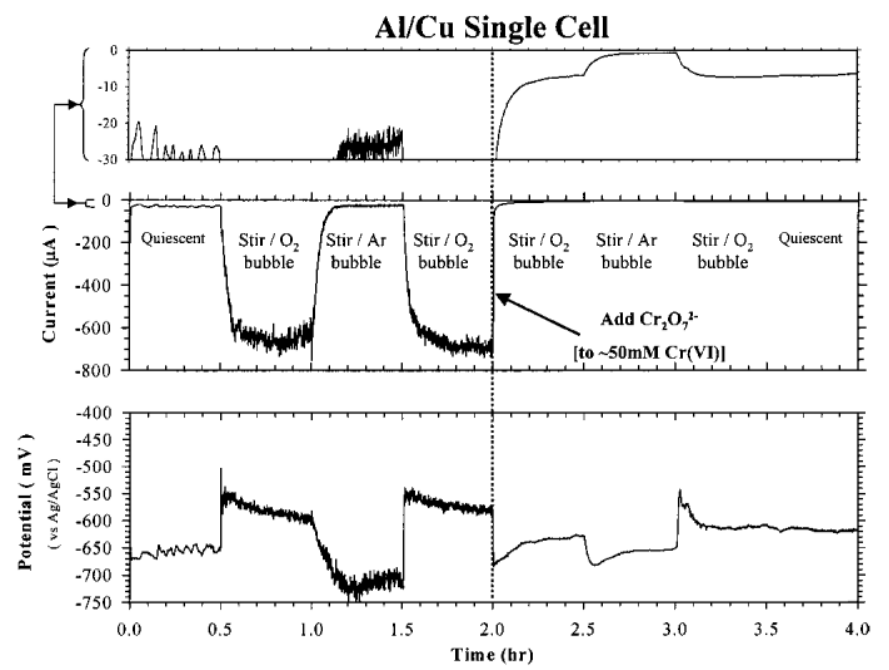

Figure 2. Current and potential vs. time plots for single cell containing pure $\mathrm{Al}\left(1 \mathrm{~cm}^{2}\right)$ and pure $\mathrm{Cu}(1 \mathrm{~cm})^{2}$ electrodes, saturated with Ar or $\mathrm{O}_{2}$ as indicated. Stirring by gas bubbles was rapid except when "quiescent'". At $t=$ $2.0 \mathrm{~h}, \mathrm{~K}_{2} \mathrm{Cr}_{2} \mathrm{O}_{7}$ solution was added to bring the total $\left[\mathrm{Cr}^{\mathrm{VI}}\right]$ to $50 \mathrm{mM}$.

less noise after $\mathrm{Cr}^{\mathrm{VI}}$ addition.

The effect of electrode pretreatment with $\mathrm{Cr}^{\mathrm{VI}}$ was studied using a quiescent single-cell aluminum-copper couple. Experiments were run in three configurations. Either the copper or the aluminum electrode was pretreated with $\mathrm{Cr}^{\mathrm{VI}}$ with the other being polished but not pretreated. These results were compared to a control experiment in which neither of the electrodes was pretreated. Results of Alodine ${ }^{\mathrm{TM}}$ 1200S pretreatment are presented in Fig. 3. Pretreatment of the 


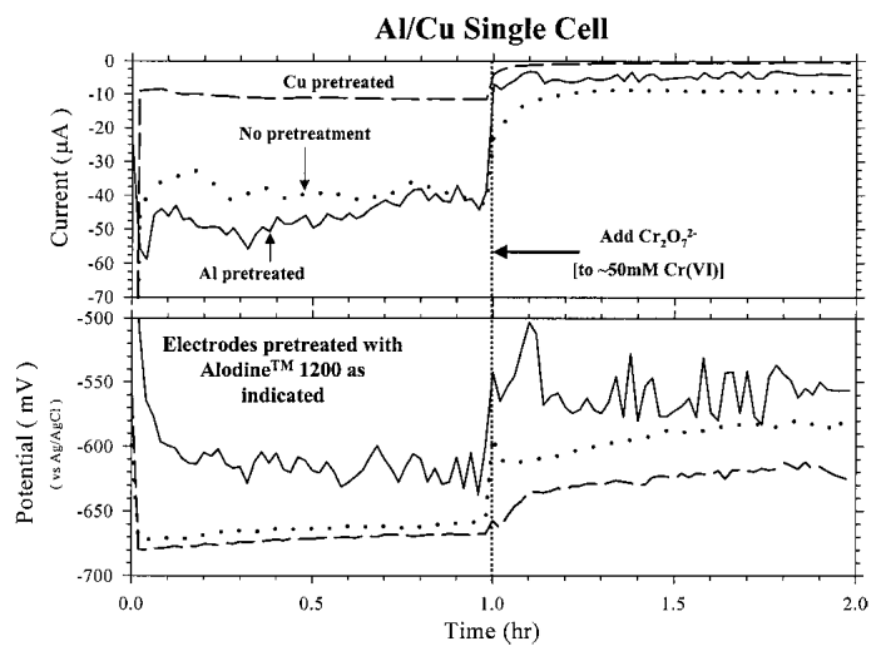

Figure 3. Behavior of the $\mathrm{Al} / \mathrm{Cu}$ single cell following pretreatment of either electrode in Alodine $1200 \mathrm{~S}$ for 5 min. The cell solution was air-saturated. At $t=1.0 \mathrm{~h}, \mathrm{~K}_{2} \mathrm{Cr}_{2} \mathrm{O}_{7}$ was added and stirred to yield a final $\left[\mathrm{Cr}^{\mathrm{VI}}\right]$ of $50 \mathrm{mM}$, after which the solution was quiescent.

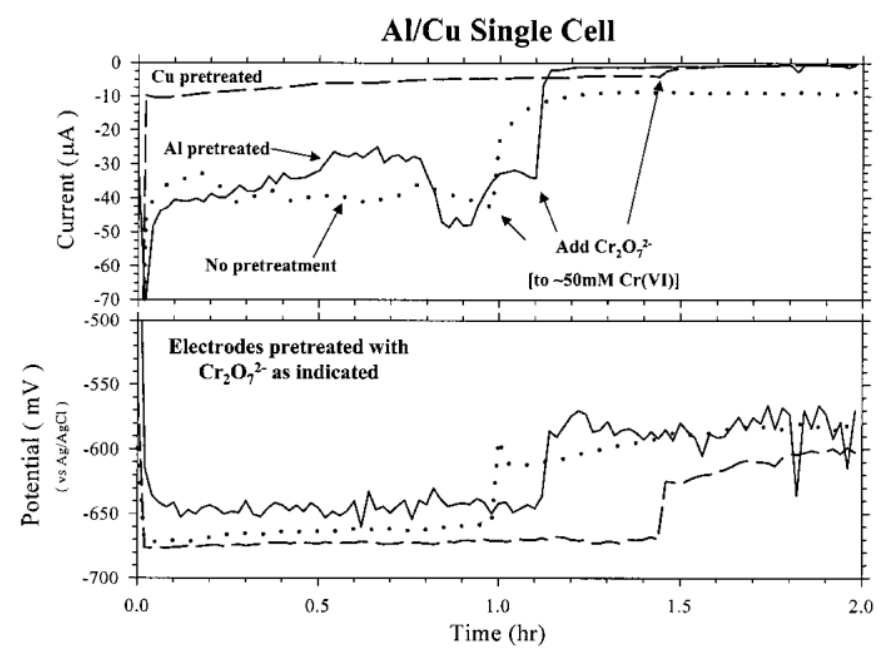

Figure 4. Same as Fig. 3, but samples pretreated by immersion in $0.40 \mathrm{M} \mathrm{K}_{2} \mathrm{Cr}_{2} \mathrm{O}_{7}$ for 2 h. $\mathrm{K}_{2} \mathrm{Cr}_{2} \mathrm{O}_{7}$ was added to the solution at the times indicated.

copper electrode with Alodine 1200S resulted in an initial galvanic current significantly lower than the case for pretreatment of the aluminum electrode. Currents after Alodine pretreatment of the aluminum electrode were similar to the control, in which neither electrode was exposed to $\mathrm{Cr}^{\mathrm{VI}}$. When $\mathrm{K}_{2} \mathrm{Cr}_{2} \mathrm{O}_{7}$ was added to the solution to a final concentration of $50 \mathrm{mM} \mathrm{Cr}{ }^{\mathrm{VI}}$, the galvanic current decreased in all cases but by varying amounts. Pretreatment in $0.4 \mathrm{M} \mathrm{K}_{2} \mathrm{Cr}_{2} \mathrm{O}_{7}$ instead of Alodine 1200S yielded very similar behavior, shown in Fig. 4.

Split-cell experiments using an aluminum-copper couple were employed to further examine the individual anodic and cathodic reactions and current inhibition. The galvanic current 
and potential were monitored for aluminum-copper couples under varying conditions of mass transport and aeration. Employment of the split cell allowed stirring and aeration/deaeration to be studied in either the anodic or cathodic reaction chamber. The separation of anodic and cathodic reactions is illustrated in Fig. 5 for the $\mathrm{Al} / \mathrm{Cu}$ split cell. Alternation of $\mathrm{Ar}$ and $\mathrm{O}_{2}$ saturation in the copper side caused large variations in current, with a negative current again referring to electron flow from aluminum to copper. The same alternation of $\mathrm{Ar}$ and $\mathrm{O}_{2}$ on the $\mathrm{Al}$ side had no observable effect, indicating that $\mathrm{O}_{2}$ reduction was not active on aluminum, presumably due to

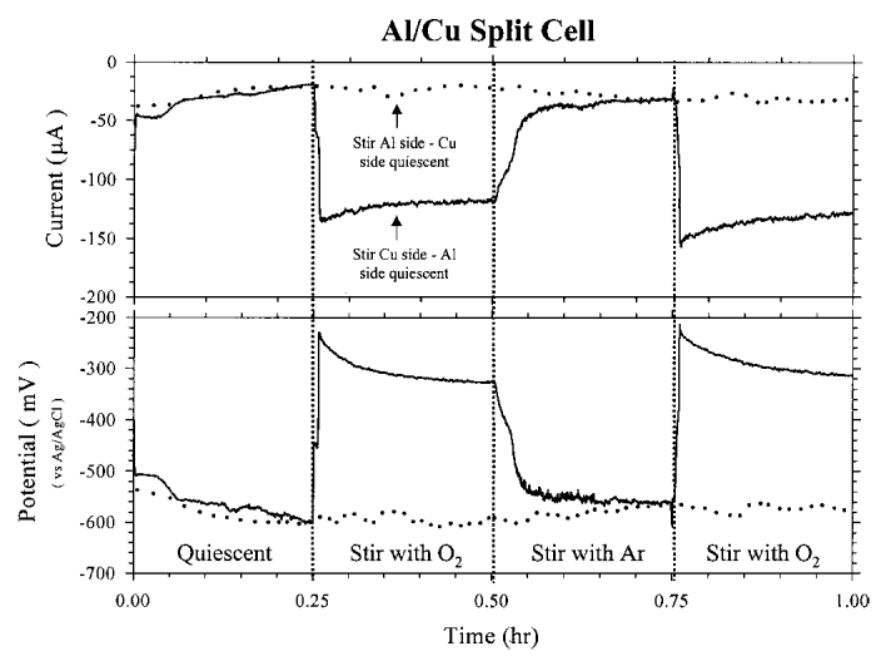

Figure 5. Current and potential behavior of split cell containing $\mathrm{Al}$ and $\mathrm{Cu}$ electrodes with $\mathrm{O}_{2}$ bubbling of either the $(\cdots) \mathrm{Al}$ or $\_$) Cu compartment as indicated. In the first (left) panel, both compartments were quiescent.

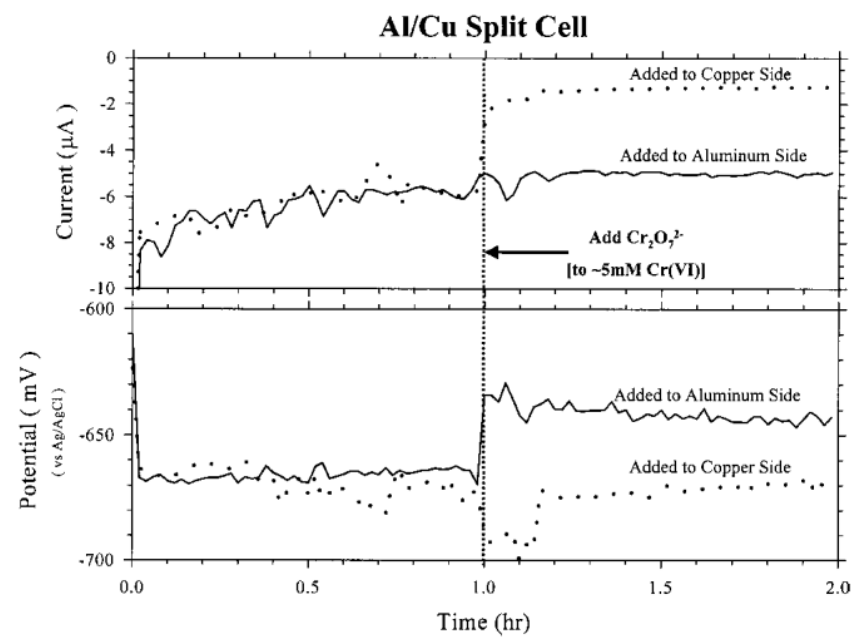

Figure 6. Effect of $\mathrm{Cr}^{\mathrm{VI}}$ addition (to $5 \mathrm{M}$ total $\mathrm{Cr}^{\mathrm{VI}}$ ) to either the $\mathrm{Al}$ or $\mathrm{Cu}$ compartments of the split cell described in Fig. 5. Both compartments were air-saturated but quiescent throughout the experiment, except for a brief mixing period after $\mathrm{Cr}^{\mathrm{VI}}$ addition. For this figure only, the $\mathrm{Cu}$ area was $0.05 \mathrm{~cm}^{2}$ and the $\mathrm{Al}$ remained at $1 \mathrm{~cm}^{2}$. 
the passive oxide film. The effect of solution $\mathrm{Cr}^{\mathrm{VI}}$ on the cathodic and anodic reactions of an aluminum-copper galvanic couple using the split-cell configuration are shown in Fig. 6. After $1 \mathrm{~h}$ of galvanic corrosion under quiescent conditions, $\mathrm{K}_{2} \mathrm{Cr}_{2} \mathrm{O}_{7}$ was added (to $\sim 5 \mathrm{mM} \mathrm{Cr}{ }^{\mathrm{VI}}$ ) to either the aluminum or copper half-cell. The galvanic current was inhibited when $\mathrm{Cr}^{\mathrm{VI}}$ was added to the copper cell, but when $\mathrm{Cr}^{\mathrm{VI}}$ was added to the aluminum cell the current remained essentially constant. The experiment was repeated with fresh electrodes and aerated solutions, with incremental addition of $\mathrm{K}_{2} \mathrm{Cr}_{2} \mathrm{O}_{7}$ to the $\mathrm{Cu}$ compartment. After stabilization of the current to -58 $\mu \mathrm{A}$, the addition of $\mathrm{Cr}_{2} \mathrm{O}_{7}^{-2}$ to yield total $\mathrm{Cr}^{\mathrm{VI}}$ concentrations of 1,10 , and $25 \mathrm{mM}$ decreased the current to $-18,-6$, and $-6 \mu \mathrm{A}$, respectively. For the same additions, the potential decreased from $-575 \mathrm{mV}$ to $-650,-680$, and $-680 \mathrm{mV}$.

Figure 7 compares current and potential profiles for a $\mathrm{Cu}$ cathode in aerated solution and either $\mathrm{Al}$ or AA2024-T3 in quiescent, aerated $0.1 \mathrm{M} \mathrm{NaCl}$. After $30 \mathrm{~min}$ of galvanic corrosion,

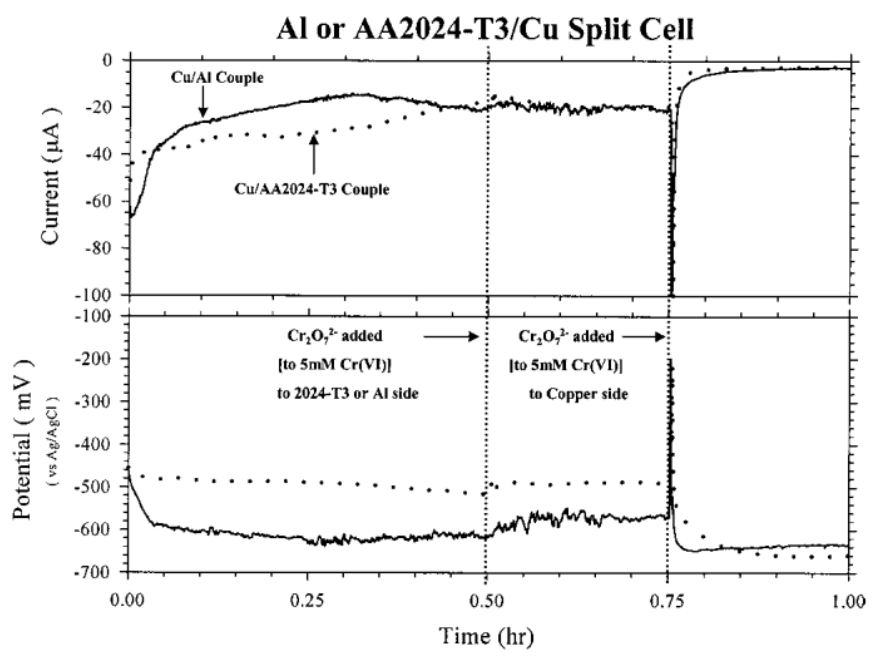

Figure 7. Behavior of split cell containing a Cu electrode in one compartment and either Al or AA2024 in the other. Both compartments were aerated but not agitated. $\mathrm{K}_{2} \mathrm{Cr}_{2} \mathrm{O}_{7}$ was added as indicated to a total $\mathrm{Cr}^{\mathrm{VI}}$ of $5 \mathrm{mM}$.

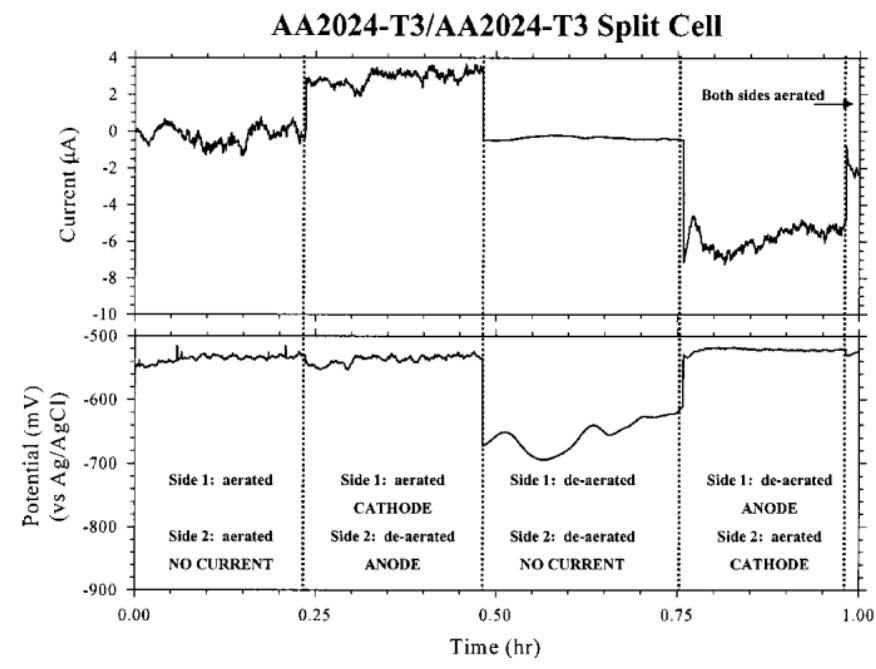


Figure 8. Behavior of split cell with AA2024 electrodes in both compartments, but with aeration of one, both, or neither compartment as indicated.

$\mathrm{K}_{2} \mathrm{Cr}_{2} \mathrm{O}_{7}$ was added (to $\sim 5 \mathrm{mM} \mathrm{Cr}^{\mathrm{VI}}$ ) to the aluminum or alloy chamber of the split cell. Fifteen minutes later $\mathrm{K}_{2} \mathrm{Cr}_{2} \mathrm{O}_{7}$ was added to the copper-containing chamber (to $\sim 5 \mathrm{mM} \mathrm{Cr}^{\mathrm{VI}}$ ). The results were similar when the copper cathode was coupled to either aluminum or AA2024-T3. The galvanic current plots for either an Al or AA2024 anode track each other for the entire experiment. Little change in current was observed for either couple when $\mathrm{Cr}^{\mathrm{VI}}$ was added to the anodic chamber. Predictably, the current dropped dramatically when $\mathrm{Cr}^{\mathrm{VI}}$ was introduced to the copper-containing chamber. The mixed potential of the copper/AA2024-T3 couple was initially higher than the copper/aluminum couple, as expected, since the measured OCP for AA2024-T3 is higher than for pure aluminum. A large current spike was observed immediately upon addition of the $\mathrm{Cr}^{\mathrm{VI}}$ to the $\mathrm{Cu}$ chamber before the current decreased below initial values. The transient was not observed when $\mathrm{Cr}^{\mathrm{VI}}$ was added to the AA2024 or Al chamber. The spike was not observable in previous experiments (Fig. 2-6), because data acquisition was paused during $\mathrm{Cr}^{\mathrm{VI}}$ addition.

With AA2024 in both sides of the split cell, galvanic corrosion current may be generated by saturating one side with air and the other with Ar. The aerated side becomes a net cathode, and the Ar side becomes a net anode. This approach is similar to differential aeration cells reported previously to study galvanic currents caused by concentration differences. ${ }^{35}$ Figure 8 demonstrates the ability to cycle the chambers between being net anodes and net cathodes by air or Ar saturation. Initially both chambers of the split cell were aerated and the resulting current fluctuated around zero under quiescent conditions. Presumably this fluctuation was caused by local corrosion events on one electrode momentarily polarizing it either positive or negative of the other electrode. Argon saturation of side 2 of the split cell yielded positive current $\left(\mathrm{e}^{-}\right.$flow toward the aerated side), and deaeration of both sides returned the current to near zero. Since both sides were deaerated, local corrosion events were minimized and the resulting "zero" current was much smoother than with both sides aerated. The mixed potential decreased as would be expected with lower oxygen concentration. As air was reintroduced into side 2, the current became negative as electrons flowed toward the aerated electrode, and the potential returned to the range of -525 to $-550 \mathrm{mV}$. The mixed potential was in this range when either or both sides were aerated and only decreased when both sides were deaerated. Inspection of both electrodes in a 2024/2024 split cell after 6 h of corrosion with differential aeration using light microscopy revealed pits on both the deaerated and aerated, with the pitting and damage being noticeably greater on the aerated side. 


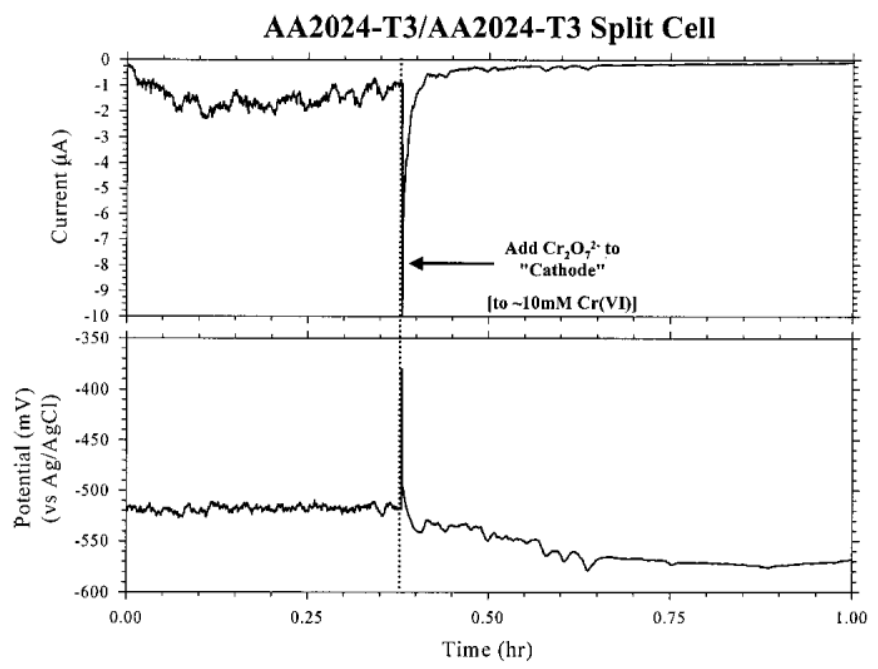

Figure 9. Effect of $\mathrm{Cr}^{\mathrm{VI}}$ addition to aerated side ("cathode") of a split cell containing AA2024 electrodes on both sides. The opposite side was Ar-saturated, but neither side was stirred except immediately after $\mathrm{Cr}^{\mathrm{VI}}$ addition.

Figures 9 and 10 show the effect of $\mathrm{Cr}^{\mathrm{VI}}$ addition on the deaerated and aerated chambers of the split cell. In both experiments a current is generated by deaeration of one side as shown in Fig. 8. Addition of $\mathrm{Cr}^{\mathrm{VI}}$ (to $\sim 10 \mathrm{mM}$ ) to either the aerated (Fig. 9) or dearated (Fig. 10) chambers caused a decrease in galvanic current, although a current spike was observed only for addition to the aerated chamber. Microscopy of both electrodes after $6 \mathrm{~h}$ of corrosion showed that $\mathrm{Cr}^{\mathrm{VI}}$ addition significantly reduced corrosion damage when added to either the deaerated or aerated side.

Figures 11 and 12 show polarization curves for $\mathrm{Cu}$ and AA2024 for conditions relevant to the split-cell experiments. Figure 11 shows the effects of $\mathrm{Cr}^{\mathrm{VI}}$ addition to aerated chloride solutions on the polarization curves for $\mathrm{Cu}$ and AA2024. The corrosion potential for AA2024 in aerated chloride solution with no $\mathrm{Cr}^{\mathrm{VI}}$ was essentially pinned at the breakdown potential due to the relative nonpolarizability of the localized corrosion reaction. In the $\mathrm{Cr}^{\mathrm{VI}}$-containing solution, the OCP was lower as a result of cathodic inhibition, and the breakdown potential was higher. In the aerated $\mathrm{Cr}^{\mathrm{VI}}$-free chloride solution, the $1 \mathrm{~cm}^{2} \mathrm{Cu}$ electrode exhibited a mass-transport-limited $\mathrm{O}_{2}$ reduction current of $40 \mu \mathrm{A} / \mathrm{cm}^{2}$ over a wide potential range between -0.30 and $-0.65 \mathrm{~V} v s$. $\mathrm{Ag} / \mathrm{AgCl}$. In the $\mathrm{Cr}^{\mathrm{VI}}$-containing solution, the rate of the cathodic reaction on $\mathrm{Cu}$ was two to 


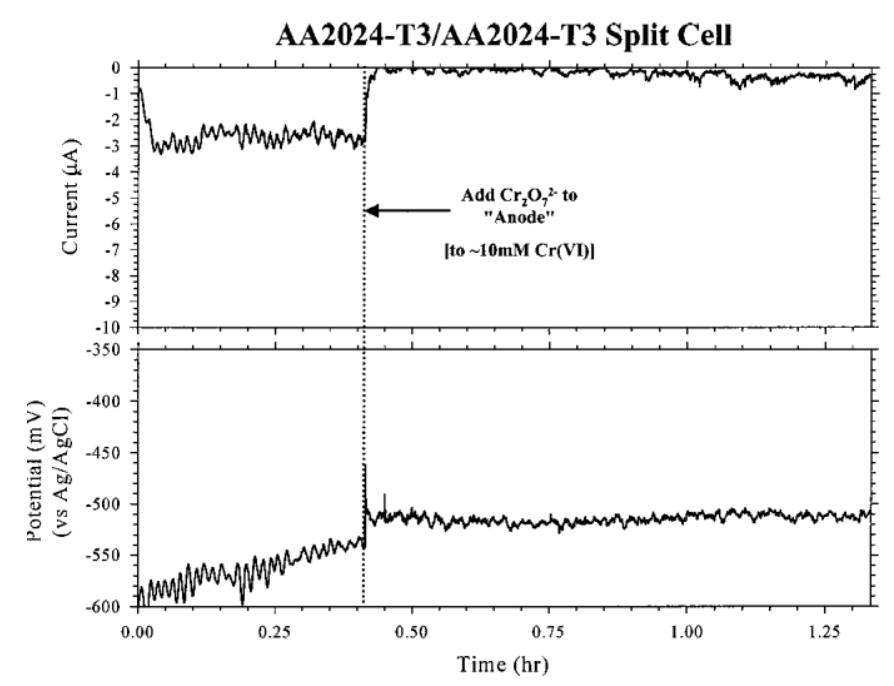

Figure 10. Same as Fig. 9 but with $\mathrm{Cr}^{\mathrm{VI}}$ addition to the deaerated chamber ("anode").

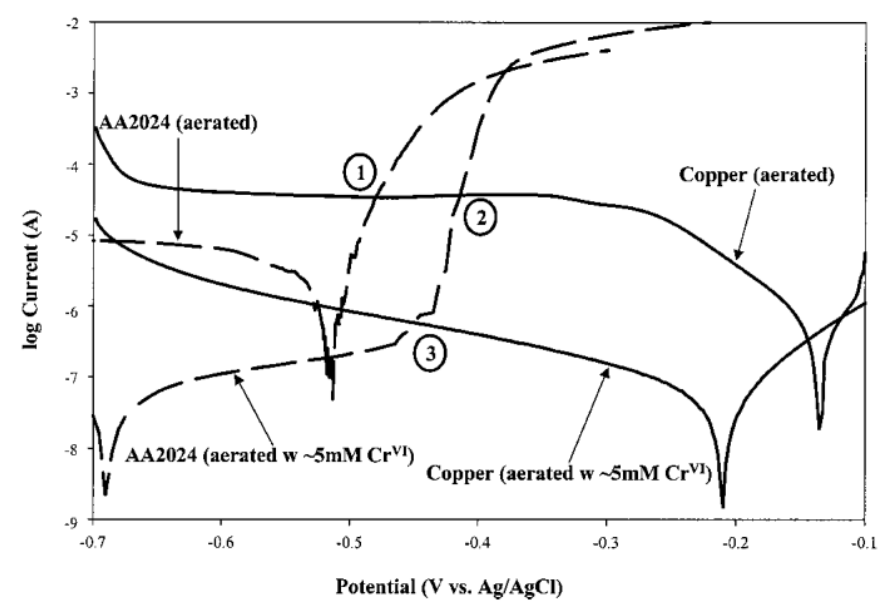

Figure 11. Potentiodynamic polarization curves for $\mathrm{Cu}$ and AA2024 electrodes in $0.1 \mathrm{M} \mathrm{NaCl}$ for the conditions shown. All electrode areas were $1 \mathrm{~cm}^{2}$. In most cases, samples were held at open circuit for $10 \mathrm{~min}$ prior to initiating a scan at $1 \mathrm{mV} / \mathrm{s}$ in the positive direction from a potential below the OCP. The exception was aerated AA2024, which was initiated at the OCP and scanned in the positive or negative direction using different samples. Labeled intersection points are described in the text.

three orders of magnitude lower. The rate of the cathodic reaction on AA2024 in the aerated $\mathrm{Cr}^{\mathrm{VI}}$ free solution was also lower than that for $\mathrm{Cu}$ in the same solution, and even lower in the $\mathrm{Cr}^{\mathrm{VI}}$ containing solution.

Figure 12 shows the polarization curves relevant to the 2024/ 2024 split-cell experiments of Fig. 9 and 10. The two curves for 2024 in aerated solutions are reproduced from Fig. 11, and the curves for AA2024 in deaerated solution are added. Deaeration or $\mathrm{Cr}^{\mathrm{VI}}$ addition resulted in a 
decrease in the cathodic current. The addition of $\mathrm{Cr}^{\mathrm{VI}}$ had less effect on the cathodic portion of the curve for AA2024 in the absence of oxygen. The passive current densities were decreased and the breakdown potentials slightly increased by the addition of $\mathrm{Cr}^{\mathrm{VI}}$.

\section{Discussion}

The objective of partial or complete separation of anodic and cathodic corrosion reactions was achieved with either the single-cell design with different electrode materials or the split cell with differential aeration. This separation permitted the localization of inhibitor effects and insights into the inhibition mechanism. However, spatial separation of the net anode and net cathode necessarily decreases chemical interactions between surface sites, which might occur in real systems when anodic and cathodic regions are in close proximity. For example, a pH change occurring at a local cathode may influence the corrosion reactions at an adjacent anode. In order to localize inhibitor effects to the anode or cathode, these chemical interactions must be neglected. With that caveat in mind, several useful observations are available from the current results and are considered in turn.

The separation of anodic and cathodic reaction for the case of pure $\mathrm{Cu}$ and pure $\mathrm{Al}$ electrodes is apparent for both the single cell (Fig. 2) and split cell (Fig. 5) and results in the observed net corrosion current. For the $\mathrm{Al} / \mathrm{Cu}$ case, the observed current was controlled by the availability of $\mathrm{O}_{2}$ at the $\mathrm{Cu}$ electrode and was increased by faster mass transport. $\mathrm{Cr}^{\mathrm{VI}}$ in solution significantly decreased the current but only if it could interact with the $\mathrm{Cu}$ electrode. In the split

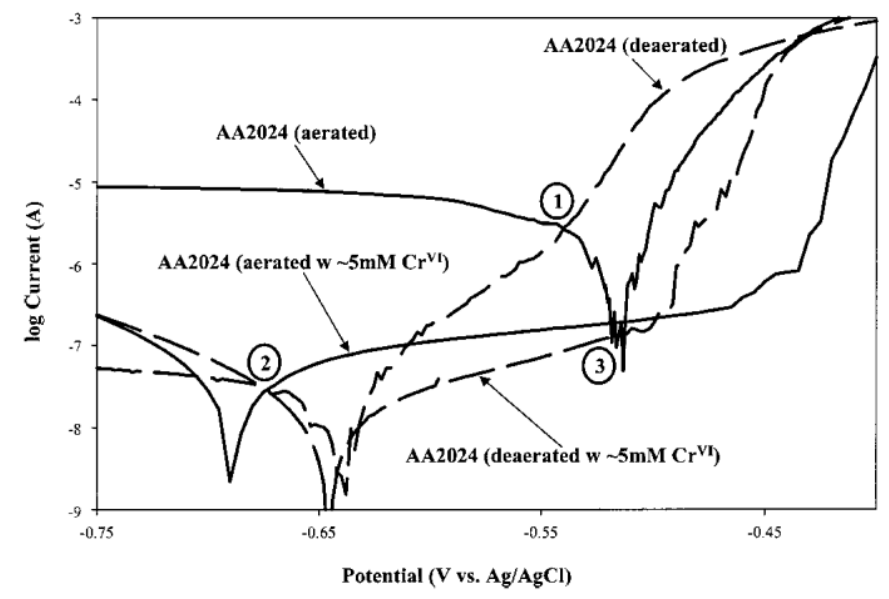

Figure 12. Potentiodynamic polarization curves for AA2024 electrodes in $0.1 \mathrm{M} \mathrm{NaCl}$ for the conditions shown. Conditions the same as those for Fig. 11.

cell, $\mathrm{Cr}^{\mathrm{VI}}$ addition to the $\mathrm{Al}$ side had no effect on the current, although it increased the potential by about $20 \mathrm{mV}$ (Fig. 6). Pretreatment of $\mathrm{Cu}$ or Al electrodes with either Alodine or $\mathrm{Cr}_{2} \mathrm{O}_{7}^{-2}$

solution (Fig. 3) had similar effects to addition of $\mathrm{Cr}^{\mathrm{VI}}$ on the galvanic corrosion cell(s). Pretreatment of $\mathrm{Cu}$ significantly suppressed the corrosion current, while pretreatment of $\mathrm{Al}$ had no effect on current and a small positive effect on potential. Taken together, the $\mathrm{Al} / \mathrm{Cu}$ experiments indicate that the observed galvanic current is limited by $\mathrm{O}_{2}$ reduction and that $\mathrm{Cr}^{\mathrm{VI}}$ 
reduces the rate of $\mathrm{O}_{2}$ reduction. At least for pure $\mathrm{Al}, \mathrm{Cr}{ }^{\mathrm{VI}}$ had no effect on the anodic reaction rate. The observations on the $\mathrm{Al} / \mathrm{Cu}$ system serve as important background information for the more realistic AA2024/Cu and AA2024/AA2024 combinations.

Separation of anodic and cathodic reactions is quite clear for the case of the $\mathrm{Cu} / \mathrm{Al}$ couple, but cells with AA2024-T3 as one or both electrodes are likely to exhibit local galvanic couples between anodic and cathodic sites on AA2024. Removal of $\mathrm{O}_{2}$ from one or both halfcells suppresses the cathodic reactions, and the observed galvanic current should be significantly larger than the local current. Based on the observed galvanic current, we identify electrodes as "net cathodes" or "net anodes". The fact that the net cathode shows more visual damage than the net anode in the AA2024/AA2024 split cell in the absence of $\mathrm{Cr}^{\mathrm{VI}}$ indicates that local reactions are significant in this case. The greater damage to the cathode may result from the generation of hydroxide ions near local cathodes, which then etch aluminum near the local cathode. Keeping the issue of imperfect separation in mind, the comparison of the $\mathrm{Cu} / \mathrm{Al}$ and $\mathrm{Cu} /$ AA2024 cells in Fig. 7 shows that the alloy behaved similarly to Al when acting as a net anode. $\mathrm{Cr}^{\mathrm{VI}}$ addition to the $\mathrm{Al}$ or $\mathrm{AA} 2024$ chamber had minor effects on galvanic current, while $\mathrm{Cr}^{\mathrm{VI}}$ inhibited the net cathodic reaction on $\mathrm{Cu}$ in both cases. The current spike observed upon $\mathrm{Cr}^{\mathrm{VI}}$ addition to the $\mathrm{Cu}$ chamber implies a transient reduction of $\mathrm{Cr}^{\mathrm{VI}}$, and the area of the spike corresponds to approximately $2 \times 10^{-9}$ mol $\mathrm{Cr}^{\mathrm{VI}}$ per $\mathrm{cm}^{2}$ of geometric copper area. No current spike was observed upon the addition of a $\mathrm{NaCl}$ solution containing no $\mathrm{Cr}^{\mathrm{VI}}$, indicating that the spike in fact resulted from the reduction of $\mathrm{Cr}^{\mathrm{VI}}$. With one prominent exception, the results for the AA2024/AA2024 split cell shown in Fig. 9 and 10 are consistent with those observed for $\mathrm{Al} / \mathrm{Cu}$ and $\mathrm{Cu} / \mathrm{AA} 2024 . \mathrm{Cr}^{\mathrm{VI}}$ inhibits the observed current when added to the aerated side of the AA2024/ AA2024 split cell (Fig. 9), similar to what was observed when it was added to the $\mathrm{Cu}$ side of the $\mathrm{Cu} / \mathrm{AA} 2024$ split cell. This again implies a cathodic inhibition mechanism for $\mathrm{Cr}^{\mathrm{VI}}$. However, $\mathrm{Cr}^{\mathrm{VI}}$ also reduces the current when added to the deaerated or "anodic" side of the AA2024/AA2024 split cell, Fig. 10. The apparent activity of $\mathrm{Cr}^{\mathrm{VI}}$ as an anodic inhibitor, which is implied by Fig. 10, is at odds with Fig. 7, in which no effect was observed on the anode when the cathode was $\mathrm{Cu}$ instead of AA2024. It also seems to contradict other results indicating that $\mathrm{Cr}^{\mathrm{VI}}$ is not an effective inhibitor for pit growth. ${ }^{18,19}$

An understanding of this behavior is provided by close examination of the polarization curves in Fig. 11 and 12. With a large $\mathrm{Cu}$ cathode, the observed corrosion current is determined by the mass-transfer-limited reduction of $\mathrm{O}_{2}$ on $\mathrm{Cu}$. The observed current and potential in the split cell (Fig. 7) are approximately equal to those predicted from Fig. 11 at the point marked "1". Under this condition, the $\mathrm{Cu}$ cathode polarized the AA2024 anode into a potential range well above the breakdown potential where localized corrosion occurred at a relatively high rate. In the galvanic corrosion condition of the split cell, the rate of the localized attack was limited by the combined cathodic reactions on the $\mathrm{Cu}$ and AA2024 surfaces. The breakdown potential for AA2024 is slightly higher in the aerated $\mathrm{Cr}^{\mathrm{VI}}$-containing solution. However, when connected to the aerated $\mathrm{Cu}$ cathode in the split cell the intersection (point 2 in Fig. 11) was still well above the breakdown potential, and the rate was still dictated by the rate of oxygen reduction on $\mathrm{Cu}$, which remained at the mass-transport-limited rate. There was little change in the current and a small positive shift in potential occurred when $\mathrm{Cr}^{\mathrm{VI}}$ was added to the AA2024 side, as observed in Fig. 7. The rate of the cathodic reaction on $\mathrm{Cu}$ was considerably lower in the $\mathrm{Cr}^{\mathrm{VI}}$-containing solution, which limited the galvanic current when $\mathrm{Cu}$ was connected to AA2024 in a solution either with or without $\mathrm{Cr}^{\mathrm{VI}}$. The shift from point 2 to 3 in Fig. 11 represents the situation when $\mathrm{Cr}^{\mathrm{VI}}$ was added to the $\mathrm{Cu}$ side in Fig. 7. 
The effect of $\mathrm{Cr}^{\mathrm{VI}}$ in the AA2024/AA2024 split-cell experiments of Fig. 9 and 10 can be understood with the help of the polarization curves in Fig. 12. The addition of $5 \mathrm{mM} \mathrm{Cr}^{\mathrm{VI}}$ increased the pitting potential of AA2024 in deaerated $0.1 \mathrm{M} \mathrm{NaCl}$ by a small amount and decreased the passive current density. The increase in pitting potential was somewhat larger in the aerated solution. These observations are evidence of a form of anodic inhibition. The polarization curve for AA2024 in the deaerated chloride solution does not show a very sharp breakdown, and galvanic coupling with an equal area of AA2024 in aerated solution brings the potential close to the inflection point in the polarization curve (point 1 in Fig. 12). When $\mathrm{Cr}^{\mathrm{VI}}$ was added to the aerated (cathodic) side of the split cell, the potential and current decreased, as shown in Fig. 9. The polarization curves predict that the potential should decrease to point 2 and that the current should decrease to the extent that the electrode polarity reverses, i.e., the AA2024 sample in the aerated chloride $+\mathrm{Cr}^{\mathrm{VI}}$ solution should become the anode. This extent of inhibition was not observed in the split-cell experiment, but a strong cathodic inhibition was evident.

The polarization curves in Fig. 12 also predict that the steady-state point should have moved from point 1 to point 3 in Fig. 12 when $\mathrm{Cr}^{\mathrm{VI}}$ was added to the deaerated side of the AA2024/AA2024 split cell. This potential is still close to the breakdown potential of both electrodes, but the passive current density in the deaerated chloride $+\mathrm{Cr}^{\mathrm{VI}}$ solution is lower than in the solution with no $\mathrm{Cr}^{\mathrm{VI}}$, and is about equal to the corrosion rate in the aerated chloride solution. The net current passing between the electrodes should be much lower and the potential should increase upon addition of $\mathrm{Cr}^{\mathrm{VI}}$, and that is in fact what was observed in Fig. 10. This observation does not contradict the prior reports that dichromate does not inhibit pit growth if one considers that sustained pit growth was not possible at point 1 in Fig. 12 where AA2024 in aerated and deaerated solutions were coupled. The decrease in current reflects a decrease in the passive current density with the addition of $\mathrm{Cr}^{\mathrm{VI}}$.

The activity of $\mathrm{Cr}^{\mathrm{VI}}$ as both an anodic and cathodic inhibitor has been reported previously by several groups, ${ }^{3,12-19}$ and there is continuing controversy about which action, if any, is dominant in corrosion protection of AA2024-T3. Ilevbare and Scully have reported that $\mathrm{Cr}^{\mathrm{VI}}$ inhibits dealloying of s-phase particles, thus reducing formation of $\mathrm{Cu}$-rich cathodic sites. ${ }^{3,12,13} \mathrm{In}$ the current work, however, the AA2024-T3 was exposed to $\mathrm{NaCl}$ solution for approximately $1 \mathrm{~h}$ before $\mathrm{Cr}^{\mathrm{VI}}$ injection (during which dealloying presumably occurred), and $\mathrm{Cr}^{\mathrm{VI}}$ still inhibited the galvanic current. Although $\mathrm{Cr}^{\mathrm{VI}}$ may inhibit dealloying in field applications, it also acts as a cathodic inhibitor on cathodic sites formed by dealloying or present initially. Furthermore, $\mathrm{Cr}^{\mathrm{VI}}$ inhibited $\mathrm{O}_{2}$ reduction on pure $\mathrm{Cu}$, which represents the upper limit of $\mathrm{Cu}$ dealloying and redistribution. The current results indicate that $\mathrm{Cr}^{\mathrm{VI}}$ does act as an anodic inhibitor, in particular by inhibiting the initiation of localized corrosion rather than growth. However, they also establish that $\mathrm{Cr}^{\mathrm{VI}}$ is a strong and irreversible cathodic inhibitor, which can play a dominant role in the stabilization of localized attack.

Preliminary examination of the size and nature of the current spikes observed upon $\mathrm{Cr}^{\mathrm{VI}}$ addition to the cathode compartment indicate that the spike area is approximately proportional to the area of exposed copper. In addition, the spike area of approximately $10^{-4} \mathrm{C} / \mathrm{cm}^{2}$ of copper is consistent with the deposition of roughly a monolayer of $\mathrm{Cr}^{\mathrm{III}}$ oxyhydroxide on exposed metallic copper. The deposition of $\mathrm{Cr}^{\mathrm{III}}$ on $\mathrm{Cu}$ and AA2024-T3 and its action to inhibit $\mathrm{O}_{2}$ reduction is the subject of a future report. 


\section{Conclusions}

To better understand corrosion and its inhibition for aluminum alloy 2024-T3, an approach was taken wherein the individual anodic and cathodic reactions were partially separated and studied using various galvanic couples. The use of a split-cell configuration allows segregation of anodic and cathodic reactions and consideration of the effect of chromate on each reaction independently.

Specific conclusions are

1. Partial or complete segregation of anodic and cathodic reactions was achieved either by choice of electrode material or by differential aeration.

2. Dilute chromate solution or pretreatment with $\mathrm{Cr}^{\mathrm{VI}}$ solution greatly decreased the $\mathrm{O}_{2}$ reduction rate on both $\mathrm{Cu}$ and AA2024-T3.

3. Cathodic inhibition on $\mathrm{Cu}$ surfaces by $\mathrm{Cr}^{\mathrm{VI}}$ solution was accompanied by a transient reduction current equivalent to generation of approximately a monolayer of $\mathrm{Cr}^{\mathrm{III}}$ oxyhydroxide.

4. Anodic inhibition by $\mathrm{Cr}^{\mathrm{VI}}$ was observed for the AA2024/ AA2024 galvanic couple but not for AA2024/Cu or $\mathrm{Al} / \mathrm{Cu}$ couples. This apparent discrepancy is consistent with observed polarization curves for AA2024-T3.

\section{Acknowledgment}

This work was supported by the Air Force Office of Scientific Research, contract no. F49620-96-1-0479. The authors thank Martin Kendig and Rudy Buchheit for useful discussions during the course of this work.

The Ohio State University assisted in meeting the publication costs of this article.

\section{References}

1. G. S. Chen, M. Gao, and R. P. Wei, Corrosion, 52, 8 (1996).

2. R. G. Buchheit, R. P. Grant, P. F. Hlava, B. McKenzie, and G. L. Zender, J. Electrochem. Soc., 144, 2621 (1997).

3. G. O. Ilevbare, J. R. Scully, J. Yuan, and R. G. Kelly, Corrosion, 56, 227 (2000).

4. R. G. Buchheit, J. Electrochem. Soc., 142, 3994 (1995).

5. C.-M. Liao, J. M. Olive, M. Gao, and R. P. Wei, Corrosion, 24, 451 (1998).

6. R. P. Wei, C.-M. Liao, and M. Gao, Metall. Trans. A, 29, 1153 (1998).

7. N. Dimitrov, J. A. Mann, and K. Sieradzki, J. Electrochem. Soc., 146, 98 (1999).

8. N. Dimitrov, J. A. Mann, M. Vukmirovic, and K. Sieradzki, J. Electrochem. Soc., 147, 3283 (2000).

9. R. G. Buchheit, L. P. Montes, M. A. Martinez, J. Michael, and P. F. Hlava, J. Electrochem. Soc., 146, 4424 (1999).

10. P. Schmutz and G. S. Frankel, J. Electrochem. Soc., 145, 2285 (1998).

11. P. Schmutz and G. S. Frankel, J. Electrochem. Soc., 145, 2298 (1998).

12. G. O. Ilevbare and J. R. Scully, J. Electrochem. Soc., 148, 196 (2001).

13. G. O. Ilevbare and J. R. Scully, Corrosion, 57, 134 (2001).

14. H. Leidheiser, Jr., Y. Momose, and R. D. Granata, Corrosion, 38, 178 (1982).

15. A. A. Tidblad and G. Lindbergh, Electrochim. Acta, 36, 1605 (1991).

16. E. Akiyama and G. S. Frankel, J. Electrochem. Soc., 146, 4095 (1999).

17. P. Schmutz and G. S. Frankel, J. Electrochem. Soc., 146, 4461 (1999).

18. A. Sehgal, D. Lu, and G. S. Frankel, J. Electrochem. Soc., 145, 2834 (1998).

19. A. Sehgal, G. S. Frankel, B. Zoofan, and S. Rokhlin, J. Electrochem. Soc., 147, 140 (2000).

20. L. Xia and R. L. McCreery, J. Electrochem. Soc., 145, 3083 (1998).

21. M. W. Kendig, A. J. Davenport, and H. S. Isaacs, Corros. Sci, 34, 3083 (1993).

22. L. Xia, E. Akiyama, G. Frankel, and R. L. McCreery, J. Electrochem. Soc., 147, 2556 (2000).

23. J. Zhao, G. Frankel, and R. L. McCreery, J. Electrochem. Soc., 145, 2258 (1998). 
24. J. K. Hawkins, H. S. Isaacs, and S. M. Heald, Corros. Sci., 27, 391 (1987).

25. J. D. Ramsey and R. L. McCreery, J. Electrochem. Soc., 146, 4076 (1999).

26. M. A. Heine and M. J. Pryor, J. Electrochem. Soc., 114, 1001 (1967).

27. E. McCafferty, J. Electrochem. Soc., 137, 3731 (1990).

28. M. Kendig, R. Addison, and S. Jeanjaquet, J. Electrochem. Soc., 146, 4419 (1999).

29. G. Lindbergh and D. Simonsson, Electrochim. Acta, 36, 1985 (1991).

30. I. M. Kolthoff and A. M. S. e. Din, J. Phys. Chem., 60, 1564 (1956).

31. J. Aldykewicz, H. S. Isaacs, and A. J. Davenport, J. Electrochem. Soc., 142, 3342 (1995).

32. C.-M. Liao and R. Wei, Electrochim. Acta, 45, 881 (1999).

33. G. S. Frankel, Corros. Sci., 30, 1203 (1990).

34. D. A. Jones, Electrochem. Technol., 6, 241 (1968).

35. D. A. Jones, Principles and Prevention of Corrosion, Prentice Hall, Upper Saddle River, NJ (1996).

36. J. Devay, B. Lengyel, and L. Meszaros, Acta Chim. Acad. Sci. Hung., 62, 157 (1969).

37. J. D. Ramsey, Ph.D. Thesis, The Ohio State University, Columbus, OH (2001), p. 227. 